\title{
Between fixities and flows: Navigating place attachments in an increasingly mobile world
}

Andrés Di Massoa, Daniel R. Williamsb, Christopher M. Raymonde, Matthias Bucheckerd, Barbara Degenhardte, Patrick Devine-Wright, Alice Hertzogs, Maria Lewickah, Lynne Manzoi, Azadeh Shahrad, Richard Stedmank, Laura Verbrugge, Timo von Wirth ${ }_{\mathrm{m}}$

a Interaction and Social Change Research Group (GRICS), Social Psychology Departmental Section, University of Barcelona, Spain

b USDA Forest Service, Rocky Mountain Research Station, 240 West Prospect Road Fort Collins, Colorado, 80526, USA

c Faculty of Biological and Environmental Sciences, Faculty of Agriculture and Forestry Sciences, Helsinki Institute of Sustainability Science (HELSUS), University of

Helsinki, P.O. Box 65 00014, Helsinki, Finland

d Swiss Federal Research Institute WSL, Economics and Social Sciences Research Unit, Zürcherstrasse 111, 8903,

Birmensdorf, Switzerland

e University of Zurich, Faculty of Science, Winterthurerstrasse 190, 8057, Zürich, Switzerland

f Department of Geography, College of Life and Environmental Sciences, University of Exeter, Rennes Drive, Exeter, EX4 4RJ, UK

g Transdisciplinarity Lab, D-USYS, ETH Zürich, Switzerland

h Department of Psychology, Nicolaus Copernicus University, Toruń, Poland

i Dept of Landscape Architecture, College of Built Environments, PO Box 355734 University of Washington, Seattle, Washington, 98195, USA

j Department of Work Science, Business Economics and Environmental Psychology, Swedish University of Agricultural Sciences, Alnarp. Box 52, SE-230 53, Alnarp, Sweden

k Department of Natural Resources, Cornell University, 101 Fernow Hall, USA

I Water Engineering and Management, Faculty of Engineering Technology, University of Twente, P.0. Box 217, 7500 AE Enschede, the Netherlands

m Dutch Research Institute for Transitions (DRIFT), Erasmus University Rotterdam, Postbus 1738, 3000 DR

Rotterdam, the Netherlands

This is a pre-proof version of the article published in the Journal of Environmental Psychology.

Full reference: Di Masso, A.; Williams, D.R., Raymond, C.M., Buchecker, M., Degenhardt, B., Devine-Wright, P., Hertzog, A., Lewicka, M., Manzo, L., Shahrad, A., Stedman, R., Verbrugge, L., von Wirth, T. (2019). Between fixities and flows: Navigating place attachments in an increasingly mobile world. Journal of Environmental Psychology, 61, 125-133. 


\section{Between fixities and flows: Navigating place attachments in an increasingly mobile world}

Abstract:

This paper develops a theoretical argument for how place attachments are forged and become dynamically linked to increasingly common mobility practices. First, we argue that mobilities, rather than negating the importance of place, shift our understanding of place and the habitual ways we relate to and bond with places as distinct from a conception of place attachment premised on fixity and stability. Second, we document how the body of research on place attachment has both reinforced and contested 'sedentaristic' assumptions criticized within the so-called 'mobilities turn' in the social sciences. Third, we present a conceptual framework, built around different modes of interrelation between fixity and flow, as a way to re-theorize, link and balance the various studies of place attachment that have grappled with mobility. Finally, we sketch out the main research implications of this framework for advancing our understanding of place attachment in a mobile world.

Keywords: Mobilities, flow, fixity, place attachment 


\section{Introduction}

Diverse forms of mobility are reconfiguring how people experience places. Recent decades have seen rapid increases in non-migratory forms of mobility, such as airline travel, internet and mobile telecommunications, and international trade (Castles, Haas \& Miller, 2014; World-Statistics.org, 2018). The kinds and degree of mobility vary widely across the world, whether they arise from urban redevelopment and gentrification (Manzo, 2014a); life-stage residential changes (Buckle, 2017); 'digital age' mobile workspaces, telecommuting and peripatetic work patterns (Stokols, 2018; van der Klis \& Karsten, 2009; Wohlers \& Hertel, 2017); tourism and amenity-seeking lifestyles (Williams \& McIntyre, 2012); attempts to escape poverty and persecution (Bräuchler \& Ménard, 2017); the displacement of refugees through war and disease (Adelman, 2008); or human smuggling and trafficking (Gostin \& Roberts, 2015). Global mobility patterns have arguably intensified and have led not only to increased circulation of people but also objects, images and ideas that re-configure the "micro-geographies of everyday life" (Cresswell, 2011, p. 551).

Since the early 2000 s, the systematic exploration of these new mobilities has been at the center of an emerging interdisciplinary research field variously described as 'the mobilities turn' or 'the new mobilities paradigm' in the social sciences (Büscher \& Urry, 2009; Cresswell, 2006, 2011; Urry, 2000). The mobilities turn offers the guiding critique that "in their search for spatial ordering, the social sciences have still failed to fully recognize how the spatialities of social life presuppose, and frequently involve conflict over, both the actual and the imagined movement of people from place to place, event to event" (Hannam, Sheller \& Urry, 2006, p. 4). Social research has been mostly 'amobile' (Sheller \&Urry, 2006), taking for granted a 'sedentarist' approach to social relations that assigns moral privilege to fixity while neglecting the varied and complex ways in which people move (both physically and virtually) across the globe (Cresswell, 2006; Malkki, 1997). As Gustafson (2014, p.38) has noted, "Humanistic geographers, environmental psychologists, and community sociologists have often regarded place attachment as good (...) whereas mobility has 
been associated with uprootedness and social disintegration.". This has often involved prioritizing rootedness, spatial ordering and belonging, while portraying mobility as "threat and dysfunction" (see also Malkki, 1997).

The role of sedentarism in place attachment research deserves closer examination. In recent years, the literature has given increased attention to the role of people-place bonds in various realms of mobility, including residential mobility, tourism, work and amenity-seeking or lifestyle migration (e.g, Bailey, Devine-Wright \& Batel, 2016; Buckle, 2017; Easthope, 2009; Haynes, 2008; Williams $\&$ McIntyre, 2012). These lines of research add to previous studies addressing the changing, evolving and processual nature of place attachment as an experience forged in the interplay between fixity and mobility (see Giuliani, 2003; Gustafson, 2001a,b; Hay, 1998; Lewicka, 2013; Manzo, Kleit \& Couch, 2008).

The purpose of this paper is to provide a rationale and conceptual framework for research on place attachment that attends to more fluid experiences of place endemic to a mobile world. We first highlight the main critical points originating from the mobilities turn that are relevant to study place attachment. We then examine sedentarist assumptions underlying early place attachment research, while foregrounding how some place attachment research has, in fact, embraced mobilities in practice. Next, we propose a framework that conceptually re-organizes, integrates and clarifies the main modes of interrelation between fixities and flows featured in place attachment research, as a way to re-read and interconnect place attachment studies that grapple with mobility. Finally, we conclude by highlighting the implications of the 'fixity to flow' framework for place attachment theory and practice, delineating the continued relevance of place attachment when studying mobility dynamics.

\section{Place attachment and the mobilities turn}


Place attachment involves the bonding of people to all kinds of places at various scales (Altman \& Low, 1992; Lewicka, 2011a). Research has produced considerable diversity of conceptualizations depending on how investigators define bonds, places, and the scale of places as well as their particular disciplinary or theoretical focus (Hernandez, Hidalgo \& Ruiz, 2014; Patterson \& Williams, 2005). For example, bonds have been variously characterized as widely shared affinities for certain environmental features to highly personal and emotional connections to particular localities (Williams, 2014). Places are often operationalized as residential locations at various scales but can also include visited, nonresidential, and even imagined places (Manzo, 2005). Further complicating the terrain, place attachment is often associated with other terms including sense of place, place identity, and place dependence, with different relations between them depending on the theoretical approach (see Korpela, 2012).

In the light of common experiences of mobility, the place attachment literature would benefit from greater focus on the specific interrelationships between the fixed and the mobile in people's actual experience of place: What happens to place attachments as mobilities increase and diversify? How do different mobility patterns interact with place attachments? How do mobility-embedded place attachments enable psychological self-continuities? These questions allow for an exploration of specific ways in which mobility and place attachments are interwoven, departing from the main contributions of the mobilities turn.

\subsection{Mobilities and the mobilities turn}

The mobilities turn represents an important lens of inquiry that is transforming theory, methods, analysis and practice in the social sciences. Büscher and Urry (2009) highlight five interdependent forms of mobilities that organize social life around movement, distance and absence: Corporeal travel, physical movement of objects, imaginative travel through print and visual images, virtual 
travel through digital media and communicative travel via person-to-person messages. At least four lines of reflection promoted by the mobilities turn are particularly useful for re-interpreting place attachment through a mobility lens, re-focusing on movement but also warning against its idealisation (see Hannam et al., 2006). First, the focus on movement brings to the fore notions of fluidity and an overall acknowledgement of spatial unmooring. Second, mobility research also underscores the importance of immobilities marked by spatial fixity and territorial attachment, implying that fixity is co-dependent with spatial movement and change. Third, the mobilityimmobility dialectic raises the question of power relations and the politics of place and movement, suggesting that (im)mobility resources, spatial freedom and constrictions are unevenly distributed across social categories (class, nation, ethnic background, gender, employee rank, function level etc.). Finally, and most importantly for this analysis, the mobilities turn questions normative definitions of place, understood as preferably static spatial categories connoting boundedness, stability, fixity, authenticity and container-like properties. Instead, it asks us to rethink the ontology of place and how spatial reconfigurations arising from mobility practices contribute to reshaping people's lived experience of being "located" in the world.

These theoretical claims do not mean that mobilities replace fixity as a preferred mode of existence, nor discount the beneficial consequences of having a stable, fixed living place (e.g., related to social well-being, Rollero \& De Piccoli, 2010; or providing comfort, relaxation and emotional selfregulation, Korpela, Ylén, Tyrväinen, \& Silvennoinen, 2009; Scannell \& Gifford, 2017). Rather, they re-orient the focus of inquiry to address how spatial and social experiences unfold in the dynamic interplay between movement and fixity, spatial proximity and distance and how this impacts well-being. The implications of mobility for place attachment are becoming well-known and even commonplace in disciplines such as human geography (Cresswell, 2011) and sociology (Urry, 2000). They have also long-since been acknowledged in environmental psychology (e.g. Brown \& Perkins, 1992); however, a systematic research program has not yet coalesced around this 
topic as in other disciplines. The next sections explore common sedentaristic underpinnings in place attachment research and highlight mobility-sensitive research that has looked beyond this sedentarism.

\subsection{Sedentarist assumptions and place attachment}

The intensification of $21^{\text {st }}$ century mobilities and corresponding emergence of mobilities scholarship, questions place attachment research the extent to which it has assumed a sedentarist metaphysics and how it might be re-theorized to further enrich our understanding of contemporary mobilities. The phrase 'sedentarist metaphysics' embraced by the mobilities paradigm comes from anthropologist Malkki (1997), whose primary concern was that "sedentarist assumptions about attachment to place lead us to define displacement not as a fact about sociopolitical context but as an inner, pathological condition of the displaced" (p. 64). Though such criticism may be attributable to differences in disciplinary perspective, early investigations of place attachment were often prompted by concerns over the presumed negative consequences of high residential mobility (Shumaker \& Taylor, 1983; Stokols, Shumaker \& Martinez, 1983). Similarly, human geographers (e.g., Relph, 1976) raised concerns about the increasing production of "placelessness" (the loss of authentic or distinctive places), which they attributed to phenomena such as high residential mobility, increasingly transitory and superficial forms of tourism, and the development of superhighways. In terms of social policies in the US and Europe, mobility was generally regarded as a threat to the rooted, moral and authentic character of places (Cresswell, 2006).

Cutting across the plurality of conceptualizations of place attachment, we propose that the early intellectual origins of place attachment research built on and often reinforced at least five sedentarist metaphysical assumptions.

Spatial proximity. Place attachment implies a wish to stay close to the attachment object such as home or residence (Bowlby, 1969; Chawla, 1992; Lewicka, 2011a). Hence, it is not surprising that most quantitative measures of place attachment reflect an individual's unwillingness to leave the 
target place (e.g., "I miss this place when I am not here," "I would like my friends and family to live here in the future," etc.).

Temporal stability. Length of contact contributes to place attachment through autobiographical memories associated with the place (Knez, 2006; Rowles, 1983; Cooper Marcus, 1992), development of quasi-automatic time-space routines (Seamon, 1980), mastery of cultural codes (Hay, 1998), and development of social bonds, including neighborhood ties (Mesch \& Manor, 1998). Length of residency and length of association with the attachment object are common predictors of attachment (Lewicka, 2011a).

Local contacts. Place attachment has also been frequently predicted by the quality of local contacts, particularly with neighbors (Lewicka, 2013; Mesch \& Manor, 1998). The relationship between attachment to place and strength of social bonds is so consistent that the latter has been used as a proxy to measure place attachment (e.g., Raymond, Brown \& Weber, 2010).

Home as a primary center of attachment. Sedentaristic concepts have pervaded scholarship on the lived experience of attachment to homeland, neighborhood and home (see Buckle, 2017; Malkki, 1997; Manzo, 2003; Williams \& McIntyre, 2001). Research on the experience of home emphasizes rootedness and the foundational role of home as the primary center of significance, stressing the benefits of proximity to that center, including explorations of one's residence as an ongoing locus of meaning over time (Korosec-Serfaty, 1984; Sixsmith, 1986).

Movement as disruptive. Research on disruptions to place attachments and the lived experience of displacement (Brown \& Perkins, 1992; Fried, 1963; Manzo, 2014b) has emphasized movement as a threat, loss, challenge or interruption of established ties with a life-environment, understood as an existential baseline. However, the disruption of place attachment as related to fixed and stable places may involve ambivalent feelings, highlighting critical distinctions in the forms, experiences and valence of mobility and disruption (Brown \& Perkins, 1992; Devine-Wright, 2009; Fullilove, 2001; Manzo, Kleit, \& Couch, 2008). 
Sedentarist assumptions are often implicit in definitions of place attachment and empirical work (Giuliani, 2003; Shumaker \& Taylor, 1983). These assumptions led researchers to pay less attention to phenomena that were inconsistent with them (e.g., see Brown \& Westaway, 2011, on spatial distance as a beneficial experience; Lewicka, 2013, on active place attachment unrelated to length of residency). Nonetheless, there has still been considerable exploration of place attachment as it pertains to various forms of mobility.

\subsection{Mobilities in place attachment research}

Different bodies of work examine attachment to visited and multiple places, as well as settlement identities, and attachments across the life-course.

Attachment to visited places. Some of the earliest attempts to empirically measure attachment looked at visits to recreation sites (Williams \& Roggenbuck, 1989). In fact, a large body of research on attachments to visited places in the form of recreation, tourism and/or nearby attractions suggest that such places are not experienced merely as places of consumption but as places with deep and lasting meaning to the visitor (Fuhrer, Kaiser \& Hartig, 1993; Korpela et al., 2009; Williams \& McIntyre, 2012).

Attachment to multiple places. A similar and significant body of research has investigated attachments to multiple places (Bonnes, Mannetti, Secchiaroli \& Tanucci, 1990; Manzo, 2005), including second homes (Gustafson, 2001b; Stedman, 2003, 2006; Williams \& Kaltenborn, 1999). This body of work generally shows that developing attachments to multiple places is a common way for people to maintain meaningful connections with family, local traditions, nature and one's self-identity.

Settlement identities. In the early 1990s, Feldman (1990) introduced the concept of settlement identity as a way to account for both constancy and change in place attachments as people change 
residence (see also Bailey, Devine-Wright \& Batel, 2016). She found that people often form bonds with particular types of residential settlements (urban, suburban, rural etc.) and that such attachments influence the types of neighborhoods people select when they move from place to place.

Attachments across the life-course. There are numerous studies examining change in attachments as people move through their life-course (Buckle, 2017), such as when leaving for university (Chow \& Healey, 2008), marriage (Hay, 1998) and with retirement (Gustafson, 2001a). These studies often point to a common theme in life-course changes that suggests people seek some kind of continuity of attachments and identity as they make place transitions across their life-course. For example, in Cooper Marcus's (1992) explorations of home, people's stories of special places were ultimately about change, adaptation, and finding creative ways to maintain or recreate attachments over time across various places in their lives.

These are just some of the ways mobility has been implicated in place attachment (see also Easthope, 2009; Gustafson, 2014). Various interpretations of 'being at home' at multiple conceptual and geographic scales also reveal flexible ways to understand attachment. These include the study of people's adaptive strategies to (re)establish or maintain a sense of self-continuity across space and time (Rishbeth \& Powell, 2013), differences in place attachment and belonging between locals and tourists or newcomers (Kaltenborn \& Williams, 2002; Kianicka et al., 2006), and dynamic approaches to mobility in process-oriented accounts of place attachment (Giuliani, 2003). Likewise, other studies illustrate how an array of places, both near and far, present and past, together create a web of meaning in our lives (Gustafson, 2001b; Manzo, 2003).

The range of studies discussed in this sub-section share a common focus on how place attachments are forged, change and develop within the context of both static and the mobile bonding. However, there has been no systematic effort to conceptually describe and integrate the underlying logics of 
fixity and flow that contribute to place attachments. The following section advances in this direction.

\section{Place attachments on the move: The 'Fixity-Flow' conceptual framework.}

As a response to the mobilities turn, we present a new framework built around a conceptual spectrum from fixity to flow that re-theorizes and re-organizes place attachment research that has engaged with mobility processes (see Figure 1). This framework defines and organizes the different modes of interrelation between fixed and fluid aspects of place attachment dynamics; that is, between the more spatially static and temporally stable aspects of place attachment as a topologically centred experience (i.e., fixity), and the more spatially mobile and temporally changing aspects of place attachment as a topologically centreless experience (i.e., flow). Between the extreme poles of fixity and flow, the framework displays how the interrelation of the two can shed light on mobility-driven place attachments.

Each of these general modes of interrelation reflects specific configurations of fixity and flow: Disruption (related to fixity); contradiction (related to fixity OR flow); complementarity and compensation (related to fixity AND flow); overarching integration (related to fixity FROM flow), multi-centred integration (related to flow IN fixities); and virtual and imaginative travel (related to flow). These configurations are supported by prototypical empirical studies addressing mobilityrelated place attachments in the literature (see Table 1). 


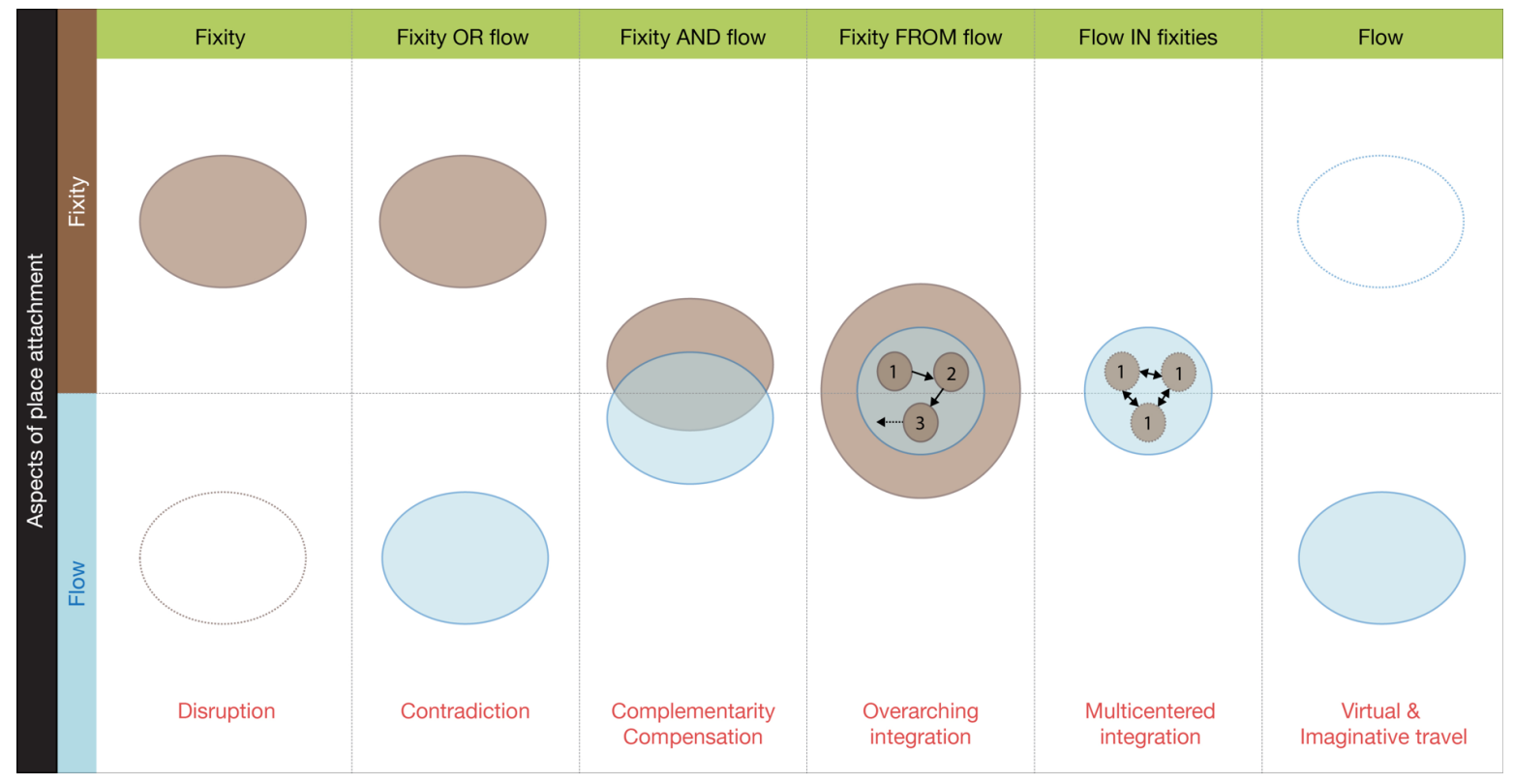

Figure 1. Fixity-flow conceptual framework with the main modes of interrelation and specific configurations between the fixed and the fluid aspects shaping place attachments ${ }^{1}$.

Table 1. Modes of interrelation and configurations of fixity-flow shaping place attachment and key examples from the literature.

\begin{tabular}{|l|l|l|l|}
\hline $\begin{array}{c}\text { Mode of } \\
\text { interrelation }\end{array}$ & \multicolumn{1}{|c|}{ Configuration } & \multicolumn{1}{c|}{ Description } & \multicolumn{1}{c|}{ Example Studies } \\
\hline Fixity & Disruption & $\begin{array}{l}\text { Moving from one place to another } \\
\text { involves psychologically } \\
\text { consequential disruption revealing } \\
\text { people's dependence on their fixed } \\
\text { life-spaces as a source of self- } \\
\text { construction, security and stability. }\end{array}$ & $\begin{array}{l}\text { Brown \& Perkins (1992); } \\
\text { Fried (1963); Fullilove } \\
\text { (2001); Manzo (2014a) }\end{array}$ \\
\hline $\begin{array}{l}\text { Fixity OR } \\
\text { Flow }\end{array}$ & $\begin{array}{l}\text { Mobility and place attachment exist } \\
\text { as two contradictory and mutually } \\
\text { exclusive themes - one must either } \\
\text { stay or leave. }\end{array}$ & Gustafson (2001b) \\
\hline
\end{tabular}

${ }^{1}$ Numbers 1, 2, 3 in "Overarching integration" represent past, present and future places connected sequentially in time through mobility; number 1 in "Multicentered integration" represents present places interconnected through mobility. 


\begin{tabular}{|c|c|c|c|}
\hline \multirow{2}{*}{$\begin{array}{l}\text { Fixity AND } \\
\text { Flow }\end{array}$} & Complementarity & $\begin{array}{l}\text { Places provide different but } \\
\text { compatible experiences: combining a } \\
\text { willingness and ability to travel with } \\
\text { an attachment to one's place of } \\
\text { residence or actively establishing } \\
\text { place connections elsewhere when } \\
\text { relocating. }\end{array}$ & $\begin{array}{l}\text { Gustafson (2009b); } \\
\text { Lewicka (2013); Bailey } \\
\text { et al. (2016) }\end{array}$ \\
\hline & Compensation & $\begin{array}{l}\text { Mobility completes what fixed place- } \\
\text { bonds might lack or fail to satisfy. } \\
\text { Mobility may not afford the kinds of } \\
\text { genuine local knowledge and self- } \\
\text { affirmation attributed to a territorially } \\
\text { rooted lifestyle. }\end{array}$ & $\begin{array}{l}\text { Stedman (2003); } \\
\text { McIntyre et al. (2006); } \\
\text { Williams \& Van Patten } \\
\text { (2006); Fuhrer et al. } \\
\text { (1993); Buchecker } \\
\text { (2009) }\end{array}$ \\
\hline $\begin{array}{l}\text { Fixity FROM } \\
\text { Flow }\end{array}$ & $\begin{array}{l}\text { Overarching } \\
\text { Integration }\end{array}$ & $\begin{array}{l}\text { Mobility between places may trigger } \\
\text { a (positive) overall sense of fixity if } \\
\text { there is: a) sense of continuity across } \\
\text { environmental types at a similar } \\
\text { geographic scale or b) place- } \\
\text { congruent self-continuity, self- } \\
\text { efficacy, distinctiveness, security or } \\
\text { aesthetic satisfaction. }\end{array}$ & $\begin{array}{l}\text { Feldman (1990); } \\
\text { Droseltis \& Vignoles } \\
\text { (2010); Twigger-Ross \& } \\
\text { Uzzell (1996) }\end{array}$ \\
\hline $\begin{array}{l}\text { Flow IN } \\
\text { Fixities }\end{array}$ & $\begin{array}{l}\text { Multi-centered } \\
\text { Integration }\end{array}$ & $\begin{array}{l}\text { Fleeting and/or shifting connections } \\
\text { between places configured as a web } \\
\text { of meaningful nodes or rhizomes that } \\
\text { resonate with each other to which the } \\
\text { individual feels place-attached, place- } \\
\text { identified or at home. }\end{array}$ & $\begin{array}{l}\text { Manzo }(2003,2005) \text {; } \\
\text { Williams \& Kaltenborn } \\
\text { (1999); Williams \& } \\
\text { McIntyre (2001) }\end{array}$ \\
\hline \multirow[b]{2}{*}{ Flow } & Virtual Travel & $\begin{array}{l}\text { Transcending geographical and often } \\
\text { social distance through information } \\
\text { and communication technologies. }\end{array}$ & Szerszyki \&Urry (2006) \\
\hline & Imaginative travel & $\begin{array}{l}\text { Being transported elsewhere through } \\
\text { the images of places and peoples } \\
\text { encountered in the media and in } \\
\text { everyday life. }\end{array}$ & $\begin{array}{l}\text { Champ et al. (2013); } \\
\text { Szerszyki \& Urry (2006) }\end{array}$ \\
\hline
\end{tabular}

Before explaining and exemplifying each of these general modes of interrelation and specific configurations of fixity and flow, two additional comments are necessary. First, the framework represents a conceptual spectrum of modes and not a sequential one. This means that transitions between one mode and another are not a given, nor are any transitions across modes necessarily assumed to be progressive during the life-course or exclusively related to length of residency. Instead, these modes should be understood as different manifestations of fixity-flow, with permeable boundaries. In this dynamic process of place attachment people navigate through different situations and contexts, be it life-stages or varying lengths of residency. Second, the poles 
of fixity and flow are theoretical abstractions. In practice, mobility is always affected by or involves some form of immobility and vice versa (see circles with dashed lines in figure 1 in the poles of fixity and flow). Mobility does not preclude a sense of stability, no matter how volatile one's geographic referents (Rishbeth \& Powell, 2013). Likewise, immobility is implicated in the social dynamics of mobility (for example, non-movers receive new arrivals, can experience imaginative, virtual travel, or the circulation of ideas, material, etc.). In other words, this framework aims to reflect the constant interpenetration of fixity and flow.

\subsection{Fixity}

Fixity represents a form of place attachment defined by a maximum degree of spatial stasis and temporal stability. Fixity manifests through immobility and a state of fusion extended in time between self and a core territory, which we refer to as topological state of absolute centeredness. This form of place bonding resembles Tuan's (1980) notion of rootedness, "a state of being made possible by an incuriosity toward the world at large and an insensitivity toward the flow of time" (p. 4), although fixity might also enable awareness and exploration of the outside world (Morgan, 2010). A fixed person is anchored in a single life-space as a unique center of meaning (e.g., a person who is born and spends his/her entire life in the house built by their grandparents).

Fixity related to mobility appears in early empirical studies of forced relocation, where disruption of place attachment is one interrelation between fixity and flow. Disruption entails that an environmental transformation and/or involuntary relocation triggers a deeply felt interruption of a personal or community-related sense of self-continuity. Moving from one place to another is usually psychologically consequential and exposes people's emotional dependence on their life-spaces as a source of self-construction, security and stability. Early research on place attachment and identity tied to environmental discontinuity has focused on forced relocations due to urban redevelopment in the US (Fried, 1963; Manzo, Kleit \& Couch, 2008). Brown and Perkins (1992) defined placerelated disruption as a stressful phase triggered by the loss of the place to which one is emotionally 
attached. Similarly, Fullilove (2001) established the notion of 'root shock,' "a traumatic stress reaction to the destruction of all or part of one's emotional eco-system" (p.11) among AfricanAmericans whose communities had been demolished by urban renewal in the second half of the 20th century. Different scholars have studied how residents emotionally react to forced relocation in terms of place attachment (e.g., Bogac, 2009; Manzo, et al., 2008). These studies illustrate that place-based feelings of security, authenticity, stability and belonging are important factors that can be experienced as conflicting with external mobility demands.

\subsection{Fixity OR flow}

While disruption reveals a fixed and rooted form of place attachment, relationships between "roots" (fixities) and "routes" (mobilities) are far more complex than implied by the modern conception of mobility as place-based disruption (Gustafson, 2001b). This conception tends to assume a globalization-driven state of placelessness among a social elite and fixed attachment among socioeconomically disadvantaged. Place attachment, then, is seen as either a negative reaction to globalizing trends or an inescapable geographical circumstance tied to social class. However, for some people mobility and fixity may coexist as different place attachment possibilities but they are experienced as irreconcilable and mutually exclusive. In Gustafson's (2001b) study in West Sweden, for example, a 40 year old woman who appreciated traveling as a form of discovering new places and opening her mind, also valued her grandparents' home as a special place of cosiness to which she had deep emotional feelings. However, she experienced the coexistence of these two forms of attachment as problematic, having to choose either one or the other ("Either you feel that here I am, or you float around”, Gustafson, 2001b, p.676). Positioning place attachment and mobility as mutually exclusive options makes them incompatible. However, mobility is not necessarily disruptive and fixity not necessarily preferred, but they can be experienced as impossible to combine without feeling uncomfortable.

\subsection{Fixity AND flow}


Significant attempts to reconcile 'home' and 'away' view these as compatible phenomena seeking 'equilibrium' (Gustafson, 2001b), either in the form of complementarity or compensation between fixity and flow. For example, many people appear to navigate between fixities and flows accepting that some form of rootedness is a pre-condition to appreciate and enjoy mobility (Morgan, 2010). In Gustafson's (2001b) study, one 30-year-old man proudly described his attachment to the farm where he had always lived as compatible with his interest in and affinity to other places far from home. Similarly, Gustafson's (2009b) research on mobile elites in Sweden demonstrated that frequent international business travelers were not detached from local concerns and commitments. In fact, localism and cosmopolitanism were complementary "resources" that combined to build a form of place attachment that conjoins a local sense of belonging and social networks, with the opportunities for openness and rich mobile experiences.

Another approach to considering fixity-flow as complementarity is to think about place attachment not as a uniform construct but as differentiated one, with different people characterized by different types of emotional bonds with places, differently related to mobility. Some forms of attachment may imply fixedness whereas others can be easily reconciled with mobility (both socio-economic and geographical). For example, Hummon (1992), on the basis of qualitative studies in a small American city, drew a distinction between everyday and ideological rootedness. The former was associated with little mobility or curiosity about the outer world (i.e., fixity), while the latter was related to mobility that is equally frequent among native-born and newcomers alike. The existence of these two types of attachment was confirmed and replicated by Lewicka $(2011 b, 2013)$ in several large quantitative studies in Poland and the Ukraine. The studies consistently showed that the everyday (traditional) form of attachment was positively correlated with the length of residency (less mobility), older age, and low education (low upward mobility). In contrast, ideological (active) attachment was unrelated to the length of residency, and was characteristic of young and middle age people, mostly educated ones. Further analyses involving additional measures of social 
capital such as trust, neighborhood ties, and values showed that whereas the traditionally attached people were strongly "localized," the actively attached combined features that were typical of strong local bonds along with more dynamic bonding (e.g. upward mobility or bridging social capital). These data suggest that as societies become more mobile, the modes of place attachment may change, too, from unreflective traditional bonds with place to self-determined active involvement on behalf of the place, making complementarity more salient (see also Savage, Bagnall, \& Longhurst, 2005).

Similar to complementarity, compensation between fixity and flow posits that mobilities might enable a form of place attachment that makes up for unsatisfactory fixed place-bonds. For example, one's place of residence can provide strong feelings of belonging, but scarce opportunities for personal exploration and new self-enhancement experiences. Several studies have shown how people made up for aspects of place attachment lacking in the home environment either by engaging in leisure mobility (Fuhrer, Kaiser \& Hartig, 1993) or bonding with non-residential places (Manzo, 2005). Buchecker (2009) showed how, on a municipal level, people who could not satisfy a personal sense of place identity in a context of social control, turned instead to recreational areas to compensate. Conversely, being constantly on the move can fulfill growth and exploration needs or desires but may not afford the kinds of local knowledge and self-affirmation typically attributed to a territorially rooted lifestyle (see Stedman, 2003; Williams \& Kaltenborn, 1999). Compensation between fixity and flow is particularly clear when mobility is not constant but periodic between different points of fixity. For example, Williams and Van Patten's (2006) research with secondhome owners in Wisconsin (USA) described how second homes can be lived as idyllic escapes, with opportunities to relax, forget work and city life, adopt a different rhythm of life, and enjoy nature.

\subsection{Fixity FROM flow}


A sense of fixity may also emerge through the permanency produced by shared features across a series of places experienced sequentially (e.g., changing residence due to work, or moving in a search for more affordable housing). Here, a sense of fixity arises from the person's integration of the different places to which one is attached, united in one same experience of place attachment. This corresponds to the relational principle of overarching integration between fixity and flow, where the idea of integration can be related to scale or to the self.

Scale-related integration involves continuity across environmental types at a similar geographic scale. For example, Feldman's (1990) research based on interviews and surveys in Denver (USA) showed that people significantly expressed more emotional affinities, positive evaluations and preferences towards types of settlements ('city' and 'suburbs') beyond specific places. The study concluded that people who frequently change residence try to preserve "the continuity of residential experiences" (Feldman, 1990, p. 186) by moving to places that are reminiscent of their former home places, thereby maintaining a "settlement-identity:" "patterns of conscious and unconscious ideas, feelings, beliefs, preferences, values, goals and behavioural tendencies and skills that relate the identity of a person to a type of settlement, and provide dispositions for the future engagement with that type of settlement” (p.192, italics added). In Feldman's study, 'suburb' and 'city' were overarching categories of places psychologically organizing people's place-preferences and choices when having to move from one place of residence to another.

A recent study of the relationship between mobility patterns, settlement identities and place attachment in the UK showed that people's attachments to their current residence was embedded in settlement identities linked to patterns of residence across the life course (Bailey et al., 2016). Active attachment was expressed by those who had consistent settlement identities (e.g. who had voluntarily relocated to a town similar in scale as other places where they had previously lived). In contrast, alienation or relativity was indicated by those with inconsistent settlement identities across the life course (e.g. those who had moved to a small town from a large city). The study also found 
evidence of individuals for whom place attachment was unreflective (i.e. who had no residential mobility and had never lived elsewhere, described as traditional attachment) and those for whom attachment to place was irrelevant (i.e. those whose life-course was characterised by high levels of residential mobility, described as placelessness).

A self-related process of overarching integration of fixity and flow posits that mobility between places may trigger a (positive) sense of fixity if there is place-congruent self-continuity (TwiggerRoss \& Uzzell, 1996). In this context, different places are interconnected because their physical and social characteristics 'fit' with the person's values. For example, in Twigger-Ross and Uzzell's (1996) interview study of the changing Surrey Docks (UK) area, place-attached residents compared the area with other places they valued, reporting fits or misfits in terms of natural scenery and valued social presences. Focusing more on aspects of social belonging, Rishbeth and Powell (2013) in the UK explored migrants' place attachment dynamics highlighting that a sense of transnational continuity emerged from bridging different life-spaces through personal memories and familiar activities in public spaces. Along these lines, self-related integration of place and mobility may also derive from other identity principles such as self-efficacy, distinctiveness, security or aesthetic satisfaction (Droseltis \& Vignoles, 2010).

\subsection{Flow IN fixities}

Integration of fixity and flow may also derive from fleeting and/or shifting connections between places configured as a web of meaningful nodes (Manzo, 2003) or rhizomes (Williams \& McIntyre, 2001) to which the individual feels attached. In this form of integration, fixity is not the dominant principle, nor is there a temporally sequential connection between successive life-spaces, but complex movement within a network of places (e.g., between home and work, between homeland and migratory destination, among multiple places of belonging, etc.) shaping place attachments according to a principle of multi-centred integration. Williams and Van Patten (2006) describe this 
pattern of place attachment as "a multicentred world in which movement and mobility play as much of a constituting role in society as more traditionally place-based notions of settlement, territory and community identity" (p. 33) such that "people need not locate their identity in a single place but, in fact, can flexibly invest themselves in a variety of places in a variety of times to suit a particular season, stage or sensibility" (p.34) in life.

Multi-centred integration is particularly clear in studies addressing how experiences of placelessness and re-placing home occur and can become intertwined in migratory processes. The notion of home has become increasingly contingent and unsettled in a mobilized world of transnational migration (Boccagni, 2017). Butcher (2010) traced the conceptualizations of home of Australian expatriates working in Asia, concluding that "mobility does not necessarily equate with relinquishing connections between home and place" but that it was observed as a "complex process of belonging to 'bits' of multiple homes" (p.23). Similarly, Fortier (2000) studied religious processions and other social activities (e.g., festivities and beauty contests) among Italian immigrant communities in two church-cum-social clubs in Britain to show how transnational communities perform their spatial belongings and attachments in a "productive tension that results from the articulation of movement and attachment, suture and departure, outside and inside, in identity formation" (p.2). Also interested in transnational place-bonding, Gustafson (2001a) studied Swedish retirees' seasonal migrations and referred to 'multiple place attachment' experiences, stemming from two contrasting transnational lifestyles labelled as 'translocal normality' and 'multilocal adaptation'. Both groups deeply felt psychological bonds with homes 'here' and 'there'. However, translocal normality was a connection to multiple places simultaneously based on similarity between places, whereas multilocal adaptation implied neighbourhood involvement, language learning and a broader identification with the country as home. 
In sum, multi-centred or 'rhizomatic' place attachments result from a constant navigation or flow between fixities configured as changing patterns of spatial anchoring and geographical circulation (Williams \& McIntyre, 2001).

\subsection{Flow}

As opposed to fixity, flow represents a maximum degree of movement, corporeal distance and territorial disconnection extended in time. In theoretical terms, it implies an experience of absence of territorial anchors and a topological sense of centrelessness. Although every human experience unavoidably takes place materially somewhere, the personal relevance of that material place can be minimal. Flow expresses a sense of transcending geographical referents that is clear in experiences of placelessness (here defined as a lack of emotional bonds to places and not needing place for life satisfaction; Bailey et al., 2016; Lewicka, 2013), but is particularly evident in imaginative and virtual travel.

Beyond the movement of bodies, imaginative travel entails being "transported elsewhere through the images of places and peoples encountered in the media" and in everyday life, whereas virtual travel involves "transcending geographical and often social distance through information and communication technologies” (Szerszynski \& Urry, 2006, p. 116). Overcoming geographical distance using one's imagination supposes a symbolic immersion into the 'atmosphere of a place' (Hannam et al., 2006), an imagined world of place-meanings that is dis-located but is equally felt and experienced from a far (e.g., a young child imagining going to Disneyland). Imaginative travel can re-create, maintain or change place attachment by activating shared representations and memories of places left behind (e.g., migrants' transnational bonds with their homelands; see Rishbeth \& Powell, 2013), and/or by psychologically anticipating and motivating different forms of mobility to places, often represented in the media and in the shared cultural imaginaries as lands of consumption, leisure, enjoyment, working opportunities, refuge, seasonal retirement, etc. (Williams \& McIntyre, 2012). 
Virtual travel involves transcending spatial distance via the use of fixed or mobile telephones and the Internet, jointly or without corporeal mobility (Champ, Williams \& Lundy, 2013). In virtual travel, flow transcends fixity by assembling the experiences of 'being here,' 'being on the move' and 'being there' at the same time, for instance when engaging in a videoconference while being in transit in an airport, or in other sites of virtual connectivity (i.e., technoscapes, Adey \& Bevan, 2006). The virtual condensation of multiple distant places via digital mobilities shifts conceptions of workspaces (e.g., skype meetings via laptops while traveling on a train) and family relations (e.g., handling parental care via smartphones) (Taipale, 2014). These examples suggest that virtual flows integrate dispersed connections to multiple locations in ways that do not necessarily replace fixed places or physical travel, but rather intensify them or change their nature and the nature of attachments to those places (Champ et al., 2013).

As Szerszynski and Urry (2006, p. 115) state, virtual and imaginative mobilities foster "inhabiting the world at a distance." As such, they may complement, superpose, or simultaneously occur with multi-centred forms of place attachment. For example, Gurney et al. (2017) recently explored multiple community framings related to place attachment to the Great Barrier Reef in Australia, and their implications for sustainability challenges in the face of global environmental pressures. They showed how information-mediated mobilities make direct environmental experience unnecessary to form place attachments from afar, that nevertheless maintain and perform community's bonds to the environment. Gurney et al. conclude that "the nature of place attachment has evolved" and it can "provide a means to transcend geographic and social boundaries" (p.10080).

As defined in the conceptual framework, flow may also involve experiences of place detachment when it involves constant corporeal mobility. For example, in Bailey et al.'s (2016) study discussed earlier, discontinuities in settlement types when moving from one place to another were related to feelings of place estrangement, either in the form of place alienation (i.e., disliking one's place of residence) or place relativity (i.e., ambivalent and conditional feelings towards the place). In the 
case of high residential mobility involving recurrent relocations, respondents referred to placelessness.

\section{Implications of the fixity-flow framework for place attachment research}

The re-interpretation of place attachment dynamics through the lens of the proposed fixity-flow framework has important implications for future research. This framework accommodates plural expressions of place attachments in a mobile world, by recognising that individuals and communities may have different types, valences and intensities of place attachments depending on varying and overlapping modes of interrelation between mobility and immobility. The framework encompasses flexible place attachments, including the potentially traumatic loss of bonds due to mobility as well as their coping or adaptive value to address rapid change and disruption (e.g., migrants' re-homing, resettlement after disasters, activity-based working). This suggests that place attachments are not inherently stable psychological constructs, but rather are informed across time and space by an array of mobility conditions and the relational configurations which underpin them (complementarity, multi-centred integration, etc.). Below we highlight important theoretical, methodological and practical implications of the fixity-flow framework for future place attachment research.

\subsection{Theoretical implications}

The fixity-flow framework proposes a theoretical consideration of place attachment that is more 'fluid' and relational, in line with Massey's (1994) notion of a global sense of place, one that is increasingly prominent in human geography (see Cresswell, 2015; Williams, 2014). Accordingly, such fluidity exhibits network-like, multiscale, dynamic qualities, based on properties that emerge from the amalgamation of local and more distant places. The resulting place attachments are continuously re-articulated and open to change as a person navigates different moments of 
interrelation between fixity and flow across an interconnected web of moorings. This view encompasses changes across life-spans as well as across personally meaningful places. Fluidity, speed, distance, scale and physicality of movement are seen here as varying attributes of movement that constitute ongoing place attachment practices. This approach to place and place attachment supports a view of place identities as 'rhizomatic' configurations (see Deleuze \& Guattari, 1987) or 'assemblages' (Cresswell, 2015), which spread feelings of anchoring and rootedness across multiple, dynamic and changing locales (see also Di Masso \& Dixon, 2015; Manzo, 2005; Williams \& McIntyre, 2001). In this way, place attachment can be viewed as an emergent property of a complex system. In such systems people learn, adapt and evolve new repertoires of behavior, effectively "making and remaking the system (i.e., making places) through imagination, discourse, and (material) action" (Williams, 2018, p. 289). Likewise, the understanding of "embodied ecosystems' suggests that people-place bonds are formed through dynamic webs of relations among mind, culture, body and the environment that become actualized in situated and dynamic ways (Raymond, Giusti, \& Barthel, 2017).

A second theoretical implication of the framework is a challenge to the interactionist logic where key elements (e.g., place attachment and corporeal movement) influence each other in a subjectobject relationship, provoking changes in one or in both (Raymond et al., 2017). The framework questions taken-for-granted assumptions about the very nature of places and of people-place bonds, demanding a more flexible approach reminiscent of a transactional perspective (Brown \& Perkins, 1992). People's efforts to articulate a coherent sense of place that reconciles stasis, movement and geographical dispersal across multiple life-spaces and trajectories underscore the extent to which individuals and communities become involved in dynamic, spatially distributed constellations of relationships with places that flexibly re-shape their feelings and beliefs about 'being located', 'being on the move' and related 'locational' practices.

Third, the fixity-flow framework raises questions about how geopolitical reconfigurations triggered by mobility practices may foreground the micro-politics of place and mobility (Di Masso, Dixon, \& 
Hernández, 2017; Ingalls \& Stedman, 2016). It can orientate place attachment research to consider how fluid people-place bonds are forged within specific constellations of (im)mobility that channel power relations. For instance, place attachment disruption derived from forced relocation can bring to the fore issues of power and social justice (Manzo, 2014a), and a permanent state of multicenteredness linked to business mobility might evidence socio-economic elite forms of privileged cosmopolitanism (Gustafson, 2009b).

\subsection{Methodological implications}

The fixity-flow framework also raises important methodological questions. First, in terms of research design, we call for more longitudinal studies of how place attachment changes over time (Devine-Wright, 2014). To date, there has been a preponderance of cross-sectional research in the literature and longitudinal studies are rare (but see Chow \& Healey, 2008; Korpela et al., 2009). Second, researchers could draw more often on existing dynamic frameworks of place attachment to investigate their validity and value for understanding both fixities and flows. These include among others Brown and Perkins (1992) three-stage model of disruption to place attachment and DevineWright's (2009) five-stage framework of psychological responses to place change. Third, existing measurement tools could be extended to better capture flow as well as fixity. Many studies of place attachment apply already existing measurement scales (e.g., Williams \& Roggenbuck, 1989) that lack an explicit temporality, yet could be revised to include additional questions concerning mobility. For example, statements aiming to measure place identity (e.g., 'I feel ' $\mathrm{X}$ ' is a part of me') could capture past and future as well as present dimensions (e.g., 'I feel ' $X$ ' was part of me' and 'I feel ' $\mathrm{X}$ ' will be part of me in the future'). Fourth and finally, place attachment researchers can broaden their methodological approach to adopt what are increasingly termed 'mobile methods' (Büscher \& Urry, 2009). These are diverse, but include performative methods (e.g., cycling or walking) that are applied to conventional methods of data collection (e.g., observation or interviews), with data recorded using mobile technologies (e.g., GPS, video or smart phone). 
Walking or 'go along' interviews have already been used in place attachment research and provide rich data about the meanings and attachments associated with specific places (see Rishbeth, 2014). They also give more prominence to embodiment and sensory aspects of place experience.

\subsection{Practical implications and future research questions}

The fixity-flow framework can provide practical orientation for designing, managing and maintaining places that are affected by mobility. Places can be designed in ways that are tailored to constellations of fixity and flow salient to individuals and groups in a given social and ecological context. For example, creating flexible design and employing participatory design processes may provide a level of security and stability in the face of major place disruption; and providing housing to those in similar physical or social environments to their place of origin may help promote a sense of continuity across environmental types and thus overarching integration.

The fixity-flow framework can equip researchers to consider other important challenges. Brown and Perkins' (1992) call for new research lines on changes to place attachment at the community and local scale is still relevant - covering, for example, communal strategies after relocation following catastrophic fires to individual household losses due to evictions. The proposed framework also embraces global challenges including climate change and ecological regime shifts; renewable energy transitions; the trend towards nationalism and populist political agendas; urban change, growth and urbanization; New Ways of Working, and technological and legal transformations. For example, where do social-ecological regime shifts and other direct or indirect drivers of place change fit within the fixities-flows framework? How does one's journey through different configurations of fixity and flow re-shape perceptions of adaptive responses to climate change or technological transformations? Equally, the fixity-flow framework may invite questions about how gentrified neighbourhoods are imagined, socially constructed and sensed by those experiencing different forms of mobility related to urban change. Also, other conceptual and empirical 
explorations can benefit from focusing on the fixity-flow dialectic: How does mobility affect people's appreciation of having a place to return to? When and what kind of mobility will bring place alienation and therefore be maladaptive? Or how might extreme fixity inhibit individual development?

\section{Conclusion}

As mobilities have moved to the foreground both in lived experience and in social theory, the need to systematically conceptualize the different forms of interweaving between fixed/static and mobile/dynamic aspects of place attachment has become ever more apparent. We propose a fixityflow framework within which to investigate place attachments in a mobile world, and in doing so provide a conceptual re-organization and theoretical argument that underscore and push forward critical contributions to place research in order to tackle place attachments 'on the move.' Furthermore, examining place attachment through the lens of this fixity-flow framework offers place researchers new meta-theoretical, conceptual and methodological resources to consider how various (im)mobilities affect and re-configure place-based meanings and attachments, and how people respond to such dynamics to construct, maintain and adapt their identities and foster wellbeing in the face of accelerating global and local changes.

\section{Acknowledgements}

This manuscript is one output of the International Exploratory Workshop entitled: 'The role of Place Attachment in the contexts of migration and urbanization: Current status and future research prospects', held at ETH Zurich (Switzerland) in June 2017.

\section{Funding:}


The workshop and this work were supported by the Swiss National Science Foundation (Grant Nr.: IZ32Z0_173387), the Swiss Academy of Humanities and Social Sciences, the ETH Zurich TdLab, and the Swiss Federal Institute for Forest, Snow and Landscape Research (WSL). 


\section{References}

Adelman, H. (2008). Protracted displacement in Asia: no place to call home. Aldershot: Ashgate.

Adey, P., \& Bevan, P. (2006). Between the physical and the virtual: Connected mobility? In J. Urry \& M. Sheller (Eds.), Mobile technologies of the city. London: Routledge.

Bailey, E., Devine-Wright, P., \& Batel, S. (2016). Using a narrative approach to understand place attachments and responses to power line proposals: The importance of life-place trajectories. Journal of Environmental Psychology, 48, 200-

211.https://doi.org/10.1016/J.JENVP.2016.10.006

Boccagni, P. (2017). Migration and the Search for Home. Basingstoke: Palgrave Macmillan. Bogac, C (2009). Place attachment in a foreign settlement. Journal of Environmental Psychology, 29, 267-278.

Bonnes, M. Mannetti, L., Secchiaroli, G., \& Tanucci, G. (1990). The city as a multi-place system: An analysis of people-urban environment transactions. Journal of Environmental Psychology, $10,37-65$.

Bowlby, J. (1969). Attachment. Attachment and loss: Vol.1. New York: Basic Books.

Bräuchler, B., \& Ménard, A. (2017). Patterns of im/mobility, conflict and the re/making of identity narratives. Social Identities, 23(4). https://doi.org/10.1080/13504630.2017.1281418

Brown, B., \& Perkins, D. (1992). Disruptions in place attachment. In I. Altman \& S. M. Low (Eds.), Place attachment (pp. 279-304). New York: Plenum Press.

Brown, K., \& Westaway, E. (2011). Agency, capacity, and resilience to environmental change: Lessons from human development, well-being, and disasters. Annual Review of Environment and Resources, 36(1), 321-342. https://doi.org/10.1146/annurev-environ-052610-092905.

Buchecker, M. (2009). Withdrawal from the local public place: Understanding the process of spatial 
alienation. Landscape Research, 34(3), 279-297. https://doi.org/10.1080/01426390902867968

Buckle, C. (2017). Residential mobility and moving home. Geography Compass, 11(5), e12314. https://doi.org/10.1111/gec3.12314

Büscher, M., \& Urry, J. (2009). Mobile methods and the empirical. European Journal of Social Theory, 12(1), 99-116. https://doi.org/10.1177/1368431008099642

Butcher, M. (2010). From "fish out of water" to "fitting in": the challenge of re-placing home in a mobile world. Population, Space and Place, 16(1), 23-36. https://doi.org/10.1002/psp.575

Castles, S., Haas, H., \& Miller, M. (2014). The age of migration. International population movements in the modern world. Basingstoke: Palgrave Macmillan.

Champ, J. G., Williams, D. R., \& Lundy, C. M. (2013). An on-line narrative of Colorado wilderness: Self-in-“cybernetic space”. Environmental Communication, 7, 131-145. http://dx.doi.org/10.1080/17524032.2012.753099

Chow, K., \& Healey, M. (2008). Place attachment and place identity: First-year undergraduates making the transition from home to university. Journal of Environmental Psychology, 28(4), 362-372. https://doi.org/10.1016/j.jenvp.2008.02.011

Cresswell, T. (2006). On the move: Mobility in the modern western world. New York: Routledge.

Cresswell, T. (2011). Mobilities I: Catching up. Progress in Human Geography, 35, 550-558.

Cresswell, T. (2015). Place: An introduction ( $2^{\text {nd }}$ ed). Chichester: Wiley Blackwell.

Deleuze, G., \& Guattari, F. (1987). A thousand plateaus: Capitalism and schizophrenia. Minneapolis: University of Minnesota Press.

Devine-Wright, P. (2009). Rethinking NIMBYism: The role of place attachment and place identity in explaining place-protective action. Journal of Community \& Applied Social Psychology, 
19(6), 426-441. https://doi.org/10.1002/casp.1004

Devine-Wright, P. (2013). Think global, act local? The relevance of place attachments and place identities in a climate changed world. Global Environmental Change, 23(1), 61-69. https://doi.org/10.1016/j.gloenvcha.2012.08.003

Devine-Wright, P. (2014). 'Place attachment dynamics in a climate changed world'. In L. C. Manzo, and P. Devine-Wright (Eds.). Place attachment: advances in theory, methods and applications. London: Routledge.

Di Masso, A., \& Dixon, J. (2015). More than words: Place, discourse and struggle over public space in Barcelona. Qualitative Research in Psychology, 12(1), 45-60. https://doi.org/10.1080/14780887.2014.958387

Di Masso, A., Dixon, J., \& Hernández, B. (2017). Place attachment, sense of belonging and the micro-politics of place satisfaction. In G. Fleury-Bahi, E. Pol, \& O. Navarro (Eds.), Handbook of environmental psychology and quality of life research (pp. 85-104). Dordrecht: Springer. https://doi.org/10.1007/978-3-319-31416-7_5

Droseltis, O., \& Vignoles, V. L. (2010). Towards an integrative model of place identification: Dimensionality and predictors of intrapersonal-level place preferences. Journal of Environmental Psychology, 30(1), 23-34. https://doi.org/10.1016/J.JENVP.2009.05.006

Easthope, H. (2009). Fixed identitites in a mobile world? The relationship between mobility, place, and identity. Identities, 16, 61-82.

Feldman, R. M. (1990). Settlement-Identity. Environment and Behavior, 22(2), 183-229. https://doi.org/10.1177/0013916590222002

Fortier, A. M. (2000). Migrant belongings. Memory, space, identity. Oxford: Berg.

Fried, M. (1963). Grieving for a lost home. In L. J. Duhl (Eds.), The urban condition(pp. 151-171). 
New York: Basic Books.

Fuhrer, U., Kaiser, F. G., \& Hartig, T. (1993). Place attachment and mobility during leisure time. Journal of Environmental Psychology, 13, 309-321.

Fullilove, M. T. (2001). Root shock: The consequences of African American dispossession. Journal of Urban Health. https://doi.org/10.1093/jurban/78.1.72

Giuliani, M. V. (2003). Theory of attachment and place attachment. In M.Bonnes, T. Lee, \& M. Bonaiuto (Eds.), Psychological theories for environmental issues (pp.137-170). Hants: Ashgate.

Gostin, L. O., \& Roberts, A. E. (2015). Forced migration the human face of a health crisis. JAMA Journal of the American Medical Association, 314(20),2125-2126. https://doi.org/10.1001/jama.2015.14906

Gurney, G. G., Blythe, H. A., Adger, W.. N., Curnock, M. Faulkner, L., James, T., \&Marshall, N. A. (2017). Redefining community based on place attachment in a connected world. PNAS, 115, 10077-10082. http://doi/10.1073/pnas.1712125114.

Gustafson, P. (2001a). Retirement migration and transnational lifestyles. Ageing and Society, 21(4), 371-394. https://doi.org/10.1017/S0144686X01008327

Gustafson, P. (2001b). Roots and routes: Exploring the relationship between place attachment and mobility. Environment and Behavior, 33(5), 667-686.

https://doi.org/10.1177/00139160121973188

Gustafson, P. (2009a). Mobility and territorial belonging. Environment and Behavior, 41(4), 490508. https://doi.org/10.1177/0013916508314478

Gustafson, P. (2009b). More cosmopolitan, no less local. European Societies, 11(1), 25-47. https://doi.org/10.1080/14616690802209689 
Gustafson, P. (2014). Place attachment in an age of mobility. In L. Manzo \& P. Devine-Wright (Eds.), Place attachment: Advances in theory, methods and applications (pp. 37-48). London: Routledge.

Hannam, K., Sheller, M., \& Urry, J. (2006). Editorial: Mobilities, immobilities and moorings. Mobilities, 1(1), 1-22. https://doi.org/10.1080/17450100500489189

Hay, R. (1998). Sense of place in developmental context. Journal of Environmental Psychology, 18(1), 5-29. https://doi.org/10.1006/JEVP.1997.0060

Haynes, B. (2008). Impact of workplace connectivity on office productivity. Journal of Corporate Real Estate, 10 (4), 286-302. https://doi.org/10.1108/14630010810925145

Hernandez, B., Hildalgo, M. C., \& Ruiz, C. (2014). Theoretical and methodological aspects of research on place attachment.In L. Manzo \& P. Devine-Wright (Eds), Place attachment: Advances in theory, methods and applications (pp. 125-137). London: Routledge.

Ingalls, M. L., \& Stedman, R. C. (2016). The power problematic: exploring the uncertain terrains of political ecology and the resilience framework. Ecology and Society, 21(1), art6. https://doi.org/10.5751/ES-08124-210106

Kaltenborn, B. P., \& Williams, D. R. (2002). The meaning of place: attachment to Femundsmarka National Park, Norway, among tourist and locals. Norwegian Journal of Geography, 56, 189198.

Kianicka S., Buchecker M., Hunziker M. and Müller-Böker, U., 2006: Locals’ and tourists' sense of place: a case study in a Swiss Alpine village. Journal of Mountain Research and Development, Vol. 26, No. 1, pp. 55-63.

Kleit, R. G., \& Manzo, L. C. (2006). To move or not to move: Relationships to place and relocation choices in HOPE VI. Housing Policy Debate, 17(2), 271-308. 
https://doi.org/10.1080/10511482.2006.9521571

Knez, I. (2006). Autobiographical memories for places. Memory, 14(3), 359-377.

Korosec-Serfaty, P. (1984). The home from attic to cellar. Journal of Environmental Psychology, 4(4), 303-321.

Korpela, K. (2012). Place attachment. In S. Clayton (Ed.) The Oxford Handbook of Environmental and Conservation Psychology (pp.148-163). New York: Oxford University Press.

Korpela, K. M., Ylén, M., Tyrväinen, L., \& Silvennoinen, H. (2009). Stability of self-reported favourite places and place attachment over a 10-month period. Journal of Environmental Psychology, 29(1), 95-100. https://doi.org/10.1016/j.jenvp.2008.05.008

Lewicka, M. (2011a). Place attachment: How far have we come in the last 40 years? Journal of Environmental Psychology, 31(3), 207-230. https://doi.org/10.1016/J.JENVP.2010.10.001

Lewicka, M. (2011b). On the varieties of people's relationships with places: Hummon's typology revisited. Environment and Behavior, 43, 676-709.

Lewicka, M. (2013). Localism and activity as two dimensions of people-place bonding: The role of cultural capital. Journal of Environmental Psychology, 36, 43-53.

https://doi.org/10.1016/J.JENVP.2013.07.002

Malkki, L. (1997). National Geographic: The rooting of peoples and the territorialization of national identity among scholars and refugees. In A. Gupta \& J. Ferguson, (eds.), Culture, power place: Explorations in critical anthropology (pp.52-74). Durham, NC: Duke University Press.

Manzo, L. C. (2003). Beyond house and haven: toward a revisioning of emotional relationships with places. Journal of Environmental Psychology, 23(1), 47-61. https://doi.org/10.1016/S0272-4944(02)00074-9

Manzo, L. C. (2005). For better or worse. Exploring multiple dimensions of place meaning. Journal 
of Environmental Psychology, 25(1), 67-86.

Manzo, L. C. (2014a). Exploring the shadow side: Place attachment in the context of stigma, displacement, and social housing. In L. Manzo \& P. Devine-Wright (Eds), Place attachment: Advances in theory, methods and applications (pp. 178-190).London: Routledge.

Manzo, L. C. (2014b). On uncertain ground: being at home in the context of public housing redevelopment. International Journal of Housing Policy, 14(4), 389-410. https://doi.org/10.1080/14616718.2014.947125

Manzo, L. C., Kleit, R. G., \& Couch, D. (2008). "Moving three times is like having your house on fire once": The experience of place and impending displacement among public housing residents. Urban Studies, 45(9), 1855-1878. https://doi.org/10.1177/0042098008093381

Massey, D. (1994). A global sense of place. In Space, place and gender (pp. 146-156). Minneapolis: Blackwell.

McIntyre, N., Williams, D. R., \& McHugh, K. E. (Eds.) (2006). Multiple dwelling and tourism: negotiating place, home and identity. Wallingford: CABI. https://doi.org/10.1079/9780845931202.0000

Mesch, G. S., \& Manor, O. (1998). Social ties, environmental perception, and local attachment. Environment and Behavior, 30(4), 504-519. https://doi.org/10.1177/001391659803000405

Morgan, P. (2010). Towards a developmental theory of place attachment. Journal of Environmental Psychology, 30, 11-22.

Raymond, C. M., Brown, G., \& Weber, D. (2010). The measurement of place attachment: Personal, community and environmental connections. Journal of Environmental Psychology, 30, 422434.https://doi.org/10.1016/j.jenvp.2010.08.002

Raymond, C. M., Giusti, M., \& Barthel, S. (2017). An embodied perspective on the co-production 
of cultural ecosystem services: toward embodied ecosystems. Journal of Environmental Planning and Management, 1-22. https://doi.org/10.1080/09640568.2017.1312300

Relph, T. (1976). Place and placelessness. London: Pion Limited.

Rishbeth, C. (2014). Articulating transnational attachments through on-site narratives. In L. Manzo and P. Devine-Wright (Eds.), Place attachment: Advances in theory, methods and applications (pp. 100-111). London: Routledge.

Rishbeth, C., \& Powell, M. (2013). Place Attachment and memory: Landscapes of belonging as experienced post-migration. Landscape Research, 38(2), 160-178.

https://doi.org/10.1080/01426397.2011.642344

Rollero, C., \& De Piccoli, N. (2010). Does place attachment affect social well-being? European Review of Applied Psychology, 60, 233-238.

Rowles, G. D. (1983). Place and personal identity in old age: Observations from Appalachia. Journal of Environmental Psychology, 3(4), 299-313. https://doi.org/10.1016/S02724944(83)80033-4

Savage, M., Bagnall, G., \& Longhurst, B. (2005). Globalization and belonging. London: Sage.

Scannell, L., \& Gifford, R. (2017). The experienced psychological benefits of place attachment. Journal of Environmental Psychology, 51, 256-269.

http://dx.doi.org/10.1016/j.jenvp.2017.04.001

Seamon, D. (1980). Body-subject, time-space routines, and place-ballets. In A. Buttimer,\& D. Seamon (Eds.), The Human Experience of Space and place(pp.148-165). New York: St. Martin's Press.

Sheller, M., \& Urry, J. (2006). The new mobilities paradigm. Environment and Planning A, 38(2), 207-226. https://doi.org/10.1068/a37268 
Shumaker, S A.,\& Taylor, R. B. (1983). Toward a clarification of people-place relationships: A model of attachment to place. In N. F. Feimer, \& E. S. Geller (Eds.), Environmental psychology: Directions \& perspectives (219-251). New York: Praeger.

Sixsmith, J. (1986). The meaning of home: An exploratory study of environmental experience. Journal of Environmental Psychology, 6, 281-298. https://doi.org/10.1016/S02724944(86)80002-0

Stedman, R. C. (2003). Is it really just a social construction?: The contribution of the physical environment to sense of place. Society and Natural Resources, 16(8), 671-685.

Stedman, R. C. (2006). Understanding place attachment among second home owners. American Behavioral Scientist, 50(2), 187-205. https://doi.org/10.1177/0002764206290633

Stokols, D. (2018). Social ecology in the digital age. London: Academic Press.

Stokols, D., Shumaker, S.A., \&Martinez, J. (1983). Residential mobility and well-being. Journal of Environmental Psychology, 3, 5-19.

Szerszynski, B., \& Urry, J. (2006). Visuality, mobility and the cosmopolitan: inhabiting the world from afar. The British Journal of Sociology, 57(1), 113-131. https://doi.org/10.1111/j.14684446.2006.00096.x

Taipale, S. (2014). The dimensions of mobilities: The spatial relationships between corporeal and digital mobilities. Social Science Research, 43, 157-167. https://doi.org/10.1016/j.ssresearch.2013.10.003

Tuan, Y. F. (1980). Rootedness versus sense of place. Landscape, 24, 3-8.

Twigger-Ross, C. L., \& Uzzell, D. L. (1996). Place and identity processes. Journal of Environmental Psychology, 16(3), 205-220. 
Urry, J. (2000). Mobile sociology. The British Journal of Sociology, 51(1), 185-203. https://doi.org/10.1111/j.1468-4446.2000.00185.x

van der Klis, M., \& Karsten, L. (2009). Commuting partners, dual residences and the meaning of home. Journal of Environmental Psychology, 29(2), 235-245. https://doi.org/10.1016/J.JENVP.2008.11.002

Williams, D. R. (2014). Making sense of “place": Reflections on pluralism and positionality in place research. Landscape and Urban Planning, 131, 74-82. https://doi.org/10.1016/j.landurbplan.2014.08.002

Williams, D. R. (2018). Spacing conservation practice: Place-making, social learning, and adaptive governance in natural resource management. In T. Marsden (Ed.), The SAGE handbook of nature, v3 (pp. 285-303). London: Sage.

Williams, D. R., \& Kaltenborn, B. P. (1999). Leisure places and modernity: The use and meaning of recreational cottages in Norway and the USA. In D. Crouch (Ed.), Leisure practices and geographic knowledge (pp. 214-230). London: Routledge.

Williams, D. R., \& McIntyre, N. (2001). Where heart and home reside: Changing constructions of place and identity. In: Trends 2000: Shaping the Future (pp. 392-403). Lansing, MI: Michigan State University.

Williams, D. R., \& McIntyre, N. (2012). Place affinities, lifestyle mobilities, and quality-of-life. In Handbook of tourism and quality-of-life research (pp. 209-231). Dordrecht: Springer. https://doi.org/10.1007/978-94-007-2288-0_12

Williams, D. R., \& Roggenbuck, J. W. (1989). Measuring place attachment: Some preliminary results. In L. H. McAvoy \& D. Howard (Eds.), Leisure Research Symposium (p. 32). Arlington, VA: National Recreation and Park Association. 
Williams, D. R., \& van Patten, S. R. (2006). Home and away? Creating identities and sustaining places in a multi-centred world. InN. McIntyre, D. Williams andK. McHugh (Eds.), Multiple dwelling and tourism: Negotiating place, home and identity(pp. 32-50). Cambridge, MA: CABI Publishing.

Wohlers, Ch., \& Hertel, G. (2017). Choosing where to work at work - towards a theoretical model of benefits and risks of activitybased flexible offices. Ergonomics, 60(4), 467-486. https://doi.org/ 10.1080/00140139.2016.1188220 